\title{
Vertical and horizontal larval distribution of an offshore brachyuran crab, Monodaeus couchii, off the south coast of Portugal
}

\author{
Patricia N. Pochelon ${ }^{1,2}$, Antonina dos Santos ${ }^{1}$, A. Miguel P. Santos ${ }^{3}$, Henrique Queiroga ${ }^{2}$ \\ ${ }^{1}$ Instituto Português do Mar e da Atmosfera (IPMA), Avenida Brasilia s/n, 1449-006 Lisbon, Portugal. \\ E-mail: ppochelon@ua.pt \\ ${ }^{2}$ CESAM, Departamento de Biologia, Campus Univeristario Santiago, Universidade de Aveiro, 3810 Aveiro, Portugal. \\ ${ }^{3}$ Instituto Português do Mar e da Atmosfera (IPMA) / CCMAR, Av. Brasilia s/n, 1449-006 Lisboa, Portugal.
}

\begin{abstract}
Summary: A strong understanding of larval distribution and abundance is of major value in delineating the location and size of a breeding population of deep-sea species such as Monodaeus couchii. In this study, vertical distribution of the larvae of a brachyuran crab, M. couchii, was assessed during two week-long cruises conducted at the end of January 2006 and 2007 off the South Coast of Portugal. Larvae were collected by oblique plankton hauls with a Longhurst-Hardy Plankton Recorder from the surface to $300 \mathrm{~m}$. Abundance and distribution of zoeae I and II were correlated during both years. For all stages, abundance decreased with depth during the day while it increased with depth at night; the larvae thus displayed reverse diel vertical migration. Abundance of zoeae I and II was correlated with chlorophyll $a$ levels, whereas those of later stages were correlated with neither physical parameters (chlorophyll $a$, temperature or salinity) nor each other. An ontogenic shift in vertical distribution explained the results; earlier zoeal stages remain in the food-rich upper water column while later stages were not correlated with any physical parameters (i.e. chlorophyll $a$, salinity or temperature) and migrated to the bottom for settlement.
\end{abstract}

Keywords: diel vertical migration; crustacean; deep sea; invertebrate larva; vertical distribution; Monodaeus couchii; Iberian Peninsula.

Distribución vertical y horizontal de larvas de Monodaeus couchii frente a la costa sur de Portugal

Resumen: El conocimiento de la distribución y abundancia larval es de vital importancia para comprender la localización y tamaño de la población reproductora adulta en especies abisales como Monodaeus couchii. En este estudio, la distribución vertical de las larvas de un cangrejo braquiuro, $M$. couchii, se evaluó durante dos campañas de una semana de duración al final de enero de 2006 y 2007, frente a la costa sur de Portugal. Las larvas se recogieron por pescas oblicuas de plancton con un "Longhurst-Hardy Plankton Recorder" (LHPR) desde la superficie hasta $300 \mathrm{~m}$ de profundidad. La abundancia y distribución de las zoeas I y II fueron correlacionadas para cada uno de los años de estudio. Para todos los estadios larvares la abundancia disminuyó con la profundidad durante el día, mientras que se incrementó con la profundidad durante la noche, mostrando por tanto un patrón de migración vertical inverso. La abundancia de zoeae I y II se correlacionó con los niveles de clorofila $a$, mientras que la abundancia de estadios posteriores no mostró correlación alguna con los parámetros físicos (clorofila $a$, temperatura o salinidad), ni entre sí. Estos resultados indican un cambio ontogénico en la distribución vertical de las larvas; los primeros estadios de zoea permanecen en la zona superficial de la columna de agua rica en alimento, mientras que las ultimas etapas que no mostraron correlación con los parámetros físicos (i.e. clorofila $a$, salinidad o temperatura) migran a zonas más profundas para el recrutamento.

Palabras clave: migración vertical diaria; crustáceo; mar profundo; larva de invertebrado; distribución vertical; Monodaeus couchii; Península Ibérica.

Citation/Como citar este artículo: Pochelon P.N., dos Santos A., Santos A.M.P., Queiroga H. 2014. Vertical and horizontal larval distribution of an offshore brachyuran crab, Monodaeus couchii, off the south coast of Portugal. Sci. Mar. 78(2): 249256. doi: http://dx.doi.org/10.3989/scimar.03944.30F

Editor: K. Anger.

Received: August 31, 2013. Accepted: March 5, 2014. Published: May 30, 2014.

Copyright: () 2014 CSIC. This is an open-access article distributed under the Creative Commons Attribution-Non Commercial Lisence (by-nc) Spain 3.0. 


\section{INTRODUCTION}

Describing the distribution, abundance and dispersal of larvae of deep-sea animals is a daunting task. The small sizes of the larvae and the very large volumes of ocean into which they may potentially disperse present difficult logistical and technical constraints (Tyler and Young 1999). In one of the most successful field studies of deep-sea larval distribution, Mullineaux et al. (1995) used a MOCNESS system to sample a neutrally buoyant plume over the Juan de Fuca Ridge (depth of sampling between 1900 and $2300 \mathrm{~m}$ ). Larval density of vent gastropods and bivalves very rapidly decreased outside the plume, illustrating the difficulty of sampling highly dilute larvae in the deep sea.

So far, field evidence on the factors that regulate dispersal of decapod larvae have been mostly based on studies of estuarine and coastal species (DeVries et al. 1994, Rothlisberg et al. 1995, DiBacco et al. 2001, Epifanio and Garvine 2001) and much less on offshore sampling programmes (e.g. Lindley 1986, dos Santos and Peliz 2005). These studies, which include laboratory studies, demonstrate a commonality of behaviours with respect to feeding, predator avoidance, swimming and vertical migration (reviewed by Queiroga and Blanton 2005). Many life-cycle traits are phylogenetically conserved in deep-sea species (Eckelbarger and Watling 1995, Tyler and Young 1999, 2003, Young 2003). Therefore, we would expect that at least some of the selective pressures and adaptations exhibited by larvae of shallow water decapods will also apply in general to deep-water species. Most decapod larvae are herbivores and/or carnivores (Anger 2001) and must therefore feed in surface layers, where light is available [ranging from the surface to $10-80 \mathrm{~m}$ in the study area, corresponding to $1 \%$ surface light intensity as defined in Navarro et al. (2006)] and therefore food concentration is higher. For deep-sea crab larvae a migration towards the surface would necessitate considerable energy investment because crab larvae are negatively buoyant (Queiroga and Blanton 2005). However, crab larvae are relatively strong swimmers capable of sustaining velocities of the order of 0.5 to $2.0 \mathrm{~cm} \mathrm{~s}^{-1}$ (Mileikovsky 1973, Chia et al. 1984), and could move over a vertical distance of $1000 \mathrm{~m}$ in a relatively short time. However, feeding in surface waters would expose them to a higher predation pressure than in the relatively protected environment of the deep-sea, and would require a return migration to deep waters at the end of planktonic life. In contrast, the upper part of the water column is usually associated with higher temperature, which typically favours faster development. Moreover, a distribution in surface waters may also have favourable consequences for horizontal dispersal and for recruitment into appropriate habitats (Pearre 1973). This tradeoff explains the different behaviours observed intra- and inter-specifically in planktonic larvae and therefore the variability in the vertical distribution of plankton (Pearre 2003).

Information on larval distributions is rare for deepsea crabs. In this short note we describe the distribution, abundance and vertical migration of Monodaeus couchii larvae. We show that the whole larval series is found in surface waters around the high chlorophyll $a$ layer, which is a depth commonly associated with high food availability (Verity et al. 2002), and that later stages are found at increasingly greater depths. Finally, we describe evidence for a reverse diel migration that may be related to predator avoidance (Han and Straskraba 2001).

\section{METHODS}

\section{Field collection}

Plankton samples were collected during two oceanographic cruises conducted off the south coast of Portugal (Fig. 1A), one from January 29 to Febru-
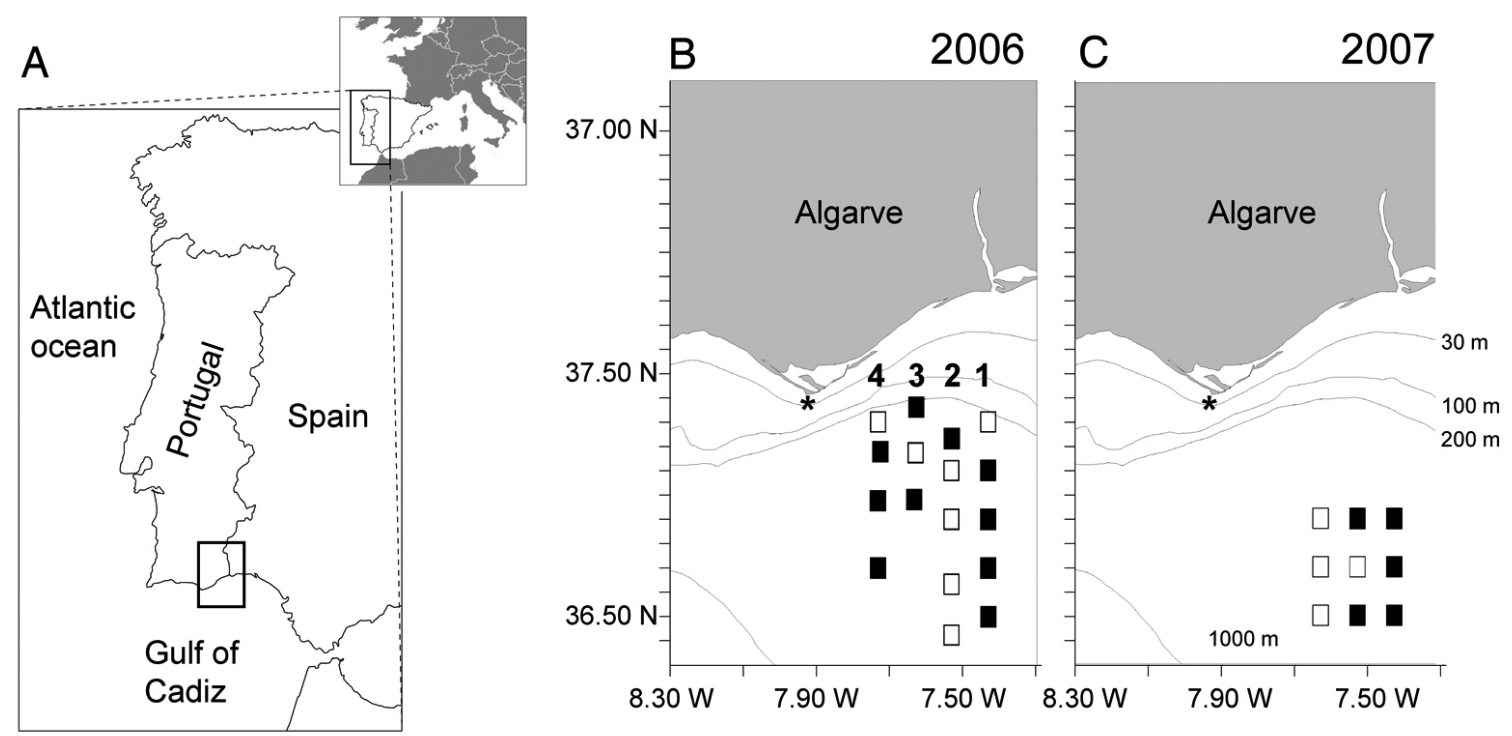

Fig. 1. - Map showing Europe and Portugal (A) and the locations of sampling sites in 2006 (B) and 2007 (C). B, sampling started on January 29, 2006 at 12:00 and ended on February 5, 2006 at 16:30. C, sampling started at station 1 on January 24, 2007 at 15:00 and ended on January

31, 2007 at 11:15. Black and white squares indicate night and day sampling, respectively; *indicates the location of Cape St Maria. 
ary 5, 2006 (17 locations: day, $n=7$; night, $n=10$; Fig. 1B) and one from January 24 to 31, 2007 (9 locations: day, $\mathrm{n}=4$; night, $\mathrm{n}=5$; Fig. $1 \mathrm{C}$ ). The sampling areas were located on the slope off the coast of Algarve, between Cape St. Maria and the Spanish border, over depths of 100 to $800 \mathrm{~m}$ (Fig. 1B,C). Samples were collected in oblique hauls with a Longhurst-Hardy Plankton Recorder (LHPR) equipped with a 42-cm cone (opening), a 280- $\mu \mathrm{m}$ mesh net and a flow meter. The water column was resolved into approximately 25-m depth strata. In 2007, vertical profiles of temperature, salinity, chlorophyll $a$ concentration and light intensity were measured with a Seabird SBE 9 plus CTD fitted with a Seapoint fluorometer and a Chelsea Instruments PAR sensor, which was deployed at each location immediately after collection of the plankton samples. Technical problems prevented the measurement of hydrological parameters in 2006. During both oceanographic cruises, the organisms sampled were fixed immediately in $4 \%$ buffered formaldehyde and brought to the laboratory for taxonomic identification (Ingle 1983a). During both cruises Monodaeus couchii were the most abundant brachyuran larvae encountered in the samples. This brachyuran crab inhabits muddy substrata (Ingle 1983b) from England to Angola and in the Mediterranean, over a bathymetric range extending from 60 to $1300 \mathrm{~m}$ (Gonzalez-Gurriarán and Méndez G. 1985). It is commonly associated with mud volcanoes, carbonate chimneys and cold seeps in the Gulf of Cadiz region (Cunha, M.R., University of Aveiro, unpublished observations). In slope habitats of the southern Iberian Peninsula and of the Mediterranean Sea, the species co-occurs with the commercially important Norway lobster Nephrops norvegicus (Gonzalez-Gurriarán and Méndez G. 1985, Maynou and Sardà 1997). Although not strictly a deep-sea species, it may provide a good model for understanding some aspects of the larval ecology of deep-sea decapod crustaceans. The larval series of Monodaeus couchii comprises 4 zoeae and 1 megalopa (Ingle 1983a). Since the number of megalopae was very low (only one larva caught in both years combined) this larval stage was not considered in the analysis. Abundances are reported as number of larvae per $100 \mathrm{~m}^{3}$.

\section{Vertical distribution}

In order to examine diel variation in catch of Monodaeus couchii, abundances were pooled into 50-m intervals, from the surface to $300 \mathrm{~m}$ for 2006 and to $200 \mathrm{~m}$ for 2007 . Due to the very low abundances of larvae caught in 2007 compared with 2006, statistical tests were performed for each year separately. Zoea IV abundances were excluded from the analysis in 2007 because only one larva was caught that year. Abundances were classified according to time of day (2 levels, day and night), larval stage (4 and 3 levels for 2006 and 2007, respectively) and depth (6 and 4 levels for 2006 and 2007, respectively) and differences were assessed using a three-way orthogonal PERMANOVA. All statistical tests were performed with Primer 6.1 with PERMANOVA add-on (Primer-E Ltd, Plym- outh, UK). All PERMANOVAs used a type III sum of squares, 9999 permutations and permutation of residuals under a reduced model. Data were transformed $[\log (\mathrm{a}+0.5)]$ before computation of the resemblance matrix using Euclidian distances. Whenever results were significant $(\mathrm{p}<0.05)$ a post-hoc comparison test was used. In order to further describe differences in depth distribution with respect to ontogenetic development, the mean depth of each stage was computed for each year using a weighted average $(\bar{d})$ accounting for differential larval abundances at each depth according to Formula (1) (Pearre 2003; dos Santos et al. 2008),

$$
\bar{d}=\frac{\sum_{i=1}^{n} A_{i} \times d_{i}}{\sum_{i=1}^{n} A_{i}}
$$

where $\bar{d}$ is the weighted mean depth and $A_{i}$ the abundance of larvae at depth $d_{i}$.

\section{Correlation between larval stage and environmen- tal parameters}

To determine whether there was a relationship between the distribution and abundance of larval stages in each year, we performed correlation analyses among abundances of the different stages, dividing the samples into $25 \mathrm{~m}$ strata. For these analyses, sampling sites with neither larval stage (double zeros) were excluded in order to avoid biasing the results. Because multiple comparisons were performed, the significance levels were adjusted using a sequential Bonferroni correction. Additionally, the correlation between larval abundance and environmental parameters (temperature, salinity and chlorophyll $a$ concentration) was assessed for 2007. Due to the non-normality of the data, even after commonly used transformation, a non-parametric Spearman correlation test was performed in all cases.

\section{RESULTS}

\section{Vertical distribution}

Overall the abundance of Monodaeus couchii was much higher in 2006 than in 2007. In addition, patches of larvae composed of different development stages were observed in 2006 (Fig. 2 marked * and \#). As expected, larvae abundance decreased as stage increased. In 2006, a significant interaction between larval stage, phase of day and depth was detected (Pseudo $\mathrm{F}=2.16$, $\mathrm{df}=15, \mathrm{p}<0.005$; Table 1; Fig. 3). The abundance of zoeae I during the day decreased with increasing depth, with higher catches at 0-50 $\mathrm{m}$ and at 50-100 $\mathrm{m}$ (post-hoc tests, $\mathrm{p}<0.048$ in all comparisons). At these depths, abundances were higher during the day than at night (post-hoc tests, $\mathrm{p}<0.004$ in all comparisons). By contrast, zoeae I abundance at night tended to increase with depth, but the differences were not statistically significant. In zoeae II, abundances displayed a similar pattern as zoeae I, but the differences between day and night catches were significant only at 0-50 m depth interval (post-hoc test, $\mathrm{p}<0.028$ ). Finally, zoeae III 

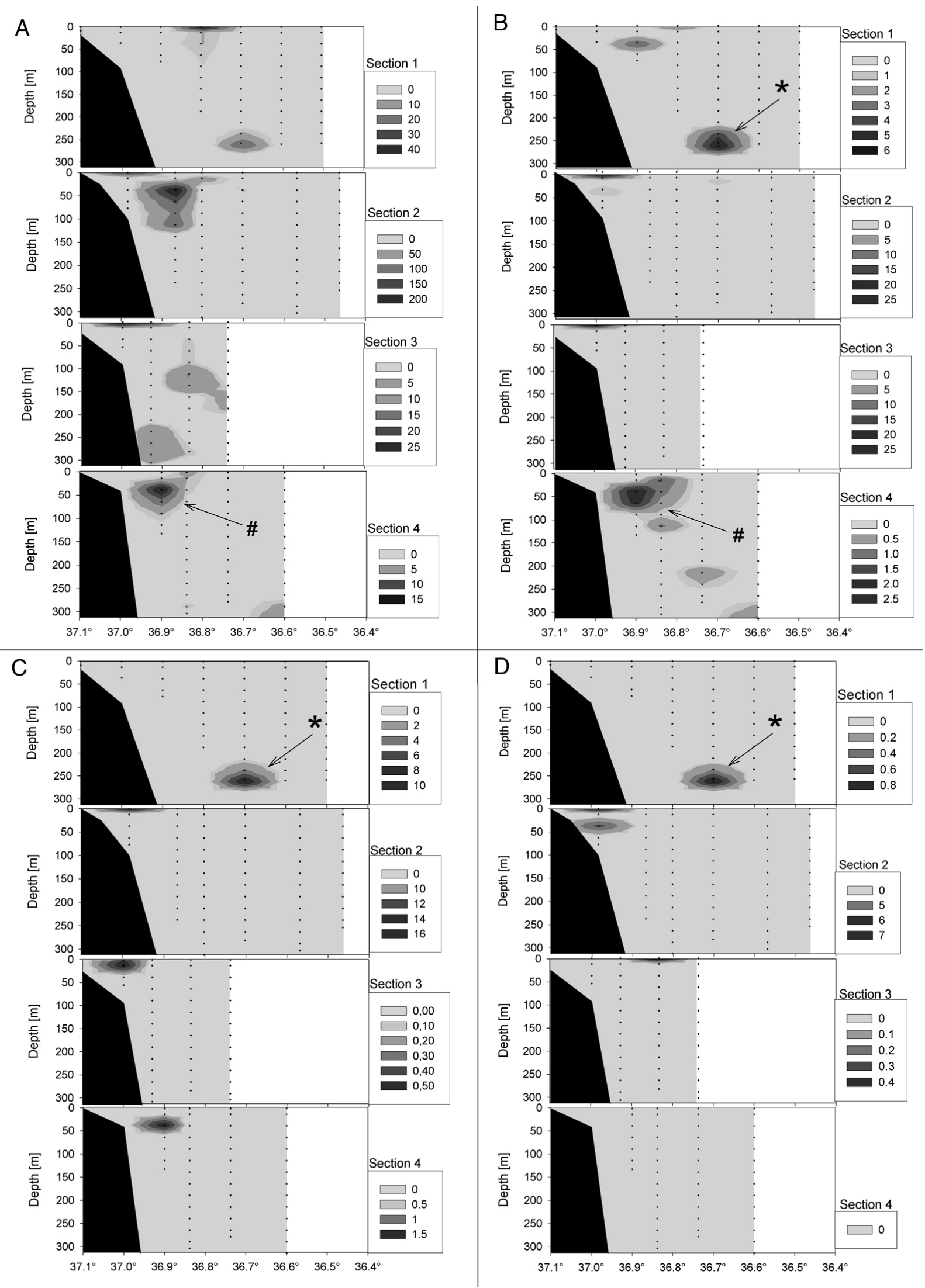

Fig. 2. - Monodaeus couchii. Contour plot of concentration (ind./100 $\mathrm{m}^{3}$ ) for zoea I (A), zoea II (B), zoea III (C) and zoea IV (D) encountered off the Algarve coast in 2006. The black shape represents sea-bottom, the black dots sampling location; * and \# represent samples where zoeae II, III and IV and zoeae I and II were simultaneously present. In each quadrant, the four sections represent transects along the longitude $7.43^{\circ} \mathrm{W}, 7.53^{\circ} \mathrm{W}, 7.63^{\circ} \mathrm{W}$ and $7.73^{\circ} \mathrm{W}$ from top to bottom, indicated in Figure 1 as transects 1 to 4 , respectively. Note that larval abundance scale varies for each zoeal stage. 
Table 1. - Monodaeus couchi. Results of the three-way PERMANOVA analysis comparing the distribution of the larval stages (4 levels: ZI, ZII, ZIII and ZIV) with respect to the phase of the day ( 2 levels: day and night) and depth (6 levels: 25, 75, 125, 175, 225 and $275 \mathrm{~m}$ ) in 2006.

\begin{tabular}{lcccc}
\hline Source & df & SS & Pseudo-F & P \\
\hline Stage (st) & 3 & 27.21 & 64.05 & 0.001 \\
Phase of day $(\mathrm{ph})$ & 1 & 1.23 & 8.66 & 0.004 \\
Depth (de) & 5 & 0.63 & 0.89 & 0.460 \\
st $\times$ ph & 3 & 1.67 & 3.92 & 0.010 \\
st $\times$ de & 15 & 1.45 & 0.68 & 0.783 \\
ph $\times$ de & 5 & 6.11 & 8.63 & 0.001 \\
st $\times$ ph $\times$ de & 15 & 4.60 & 2.16 & 0.010 \\
\hline
\end{tabular}

and IV abundances also appeared to be higher during the day at the surface while at night abundances were higher below $100 \mathrm{~m}$. These results were not significant, however, probably because of the very low numbers of zoeae III and IV (overall abundances \pm SE of $0.0638 \pm 0.0600$ ind. $/ 100 \mathrm{~m}^{3}, 0.0029 \pm 0.00006$ ind. $/ 100$ $\mathrm{m}^{3}, 0.0019 \pm 0.00009$ ind.$/ 100 \mathrm{~m}^{3}$ and $0.0012 \pm 0.00007$ ind./100 $\mathrm{m}^{3}$ for zoeae I, II, III and IV, respectively). In 2007, abundances were significantly higher during the day than at night for all stages and depths (Pseudo $\mathrm{F}=3.91, \mathrm{df}=1, \mathrm{p}<0.03$; Table 2; Fig. 4). These results must, however, be interpreted with caution since larval abundances were extremely low (overall abundances of $0.0327 \pm 0.0151$ ind. $/ 100 \mathrm{~m}^{3}, 0.0009 \pm 0.00002$ ind. $/ 100$ $\mathrm{m}^{3}, 0.0003 \pm 0.00001$ ind. $/ 100 \mathrm{~m}^{3}$ and $0.0034 \pm 0.0010$ ind./100 $\mathrm{m}^{3}$ for zoeae I, II, III and IV, respectively) and most larvae of the later stages (93\% abundance of ZIII and IV) were encountered during the day at a single sampling site.
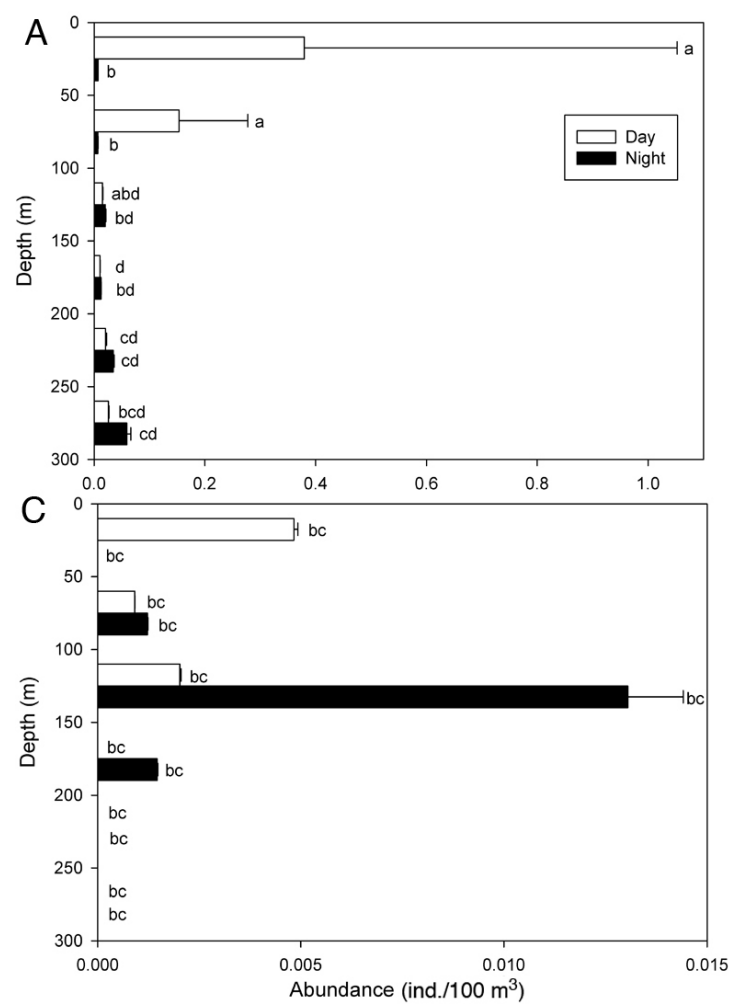

Table 2. - Monodaeus couchi. Results of the three-way PERMANOVA analysis comparing the distribution of the larval stages (3 levels: ZI, ZII, and ZIII) with respect to the phase of the day (2 levels: day and night) and depth (5 levels: $25,75,125,175$, and $225 \mathrm{~m}$ ) in 2007.

\begin{tabular}{lcccc}
\hline Source & df & SS & Pseudo-F & P \\
\hline Stage (st) & 2 & 0.87 & 2.82 & 0.062 \\
Phase of day (ph) & 1 & 0.60 & 3.91 & 0.026 \\
Depth (de) & 4 & 0.14 & 0.23 & 0.908 \\
st $\times$ ph & 2 & 0.44 & 1.43 & 0.213 \\
st $\times$ de & 8 & 0.26 & 0.21 & 0.988 \\
ph $\times$ de & 4 & 0.44 & 0.72 & 0.579 \\
st $\times$ ph $\times$ de & 8 & 0.65 & 0.53 & 0.821 \\
\hline
\end{tabular}

Finally, mean depth of larvae varied between years but overall the first stage was encountered at shallower depth than later stages, with zoeae IV average depth being the deepest (weighted average depth of distribution $( \pm \mathrm{SD})$ for both years combined was $85.7 \pm 36.8$, $119.6 \pm 43.4,109.7 \pm 54.1$ and $129.5 \pm 40.5 \mathrm{~m}$ for zoeae I to IV, respectively).

\section{Correlations among larval stages, and between larval stages and environmental parameters}

Spearman correlation $\left(r_{s}\right)$ values between the concentrations of the different zoeal stages indicated that the abundance of zoeae I and II ( $\left.\mathrm{r}_{\mathrm{s}}=0.37\right)$, zoeae I and IV $\left(r_{s}=0.30\right)$, and zoeae II and IV $\left(r_{s}=0.45\right)$ were correlated in 2006. In 2007 only the concentrations of zoeae I and II were correlated $\left(r_{\mathrm{s}}=0.75\right.$; all values significant at $\alpha=0.05$ probability level after Bonferroni correction, in 2006 and 2007). The difference in the results
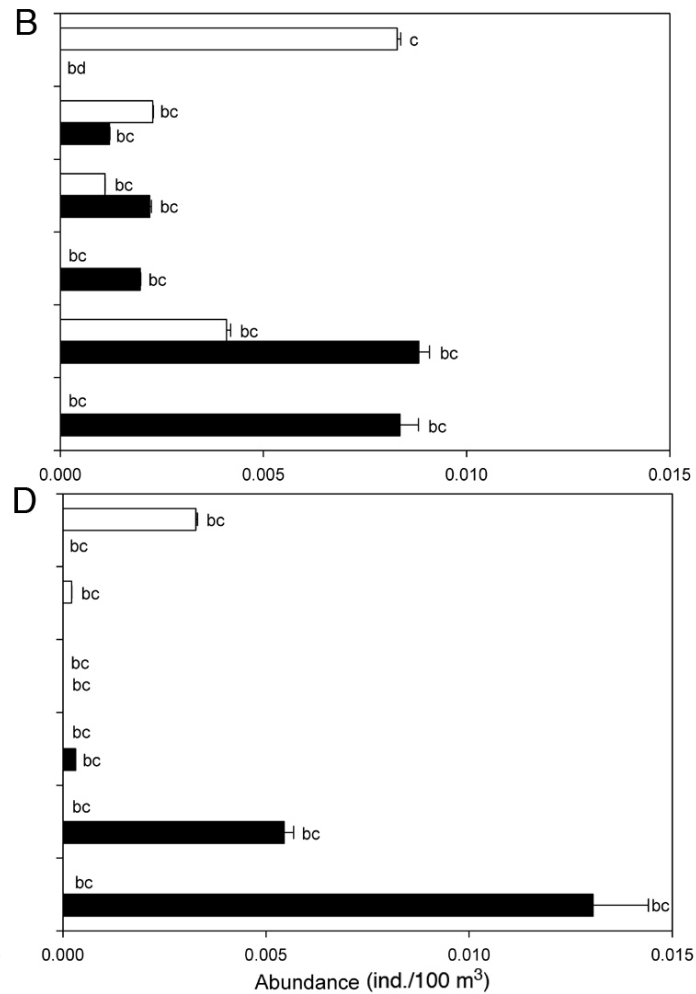

Fig. 3. - Monodaeus couchii. Abundance of larvae (ind./100 $\mathrm{m}^{3} \pm$ SE) with respect to depth for zoea I (A), zoea II (B), zoea III (C), and zoea IV (D) as a function of the phase of the day for the 2006 cruise. White and black bars represent day and night samples, respectively. At each depth, sample size was $n=7$ for the day, and $n=10$ for the night. Identical letters above bars represent statistically similar abundances according to post-hoc tests. The scale of abundance is different between zoea I and zoea II, III and IV. 

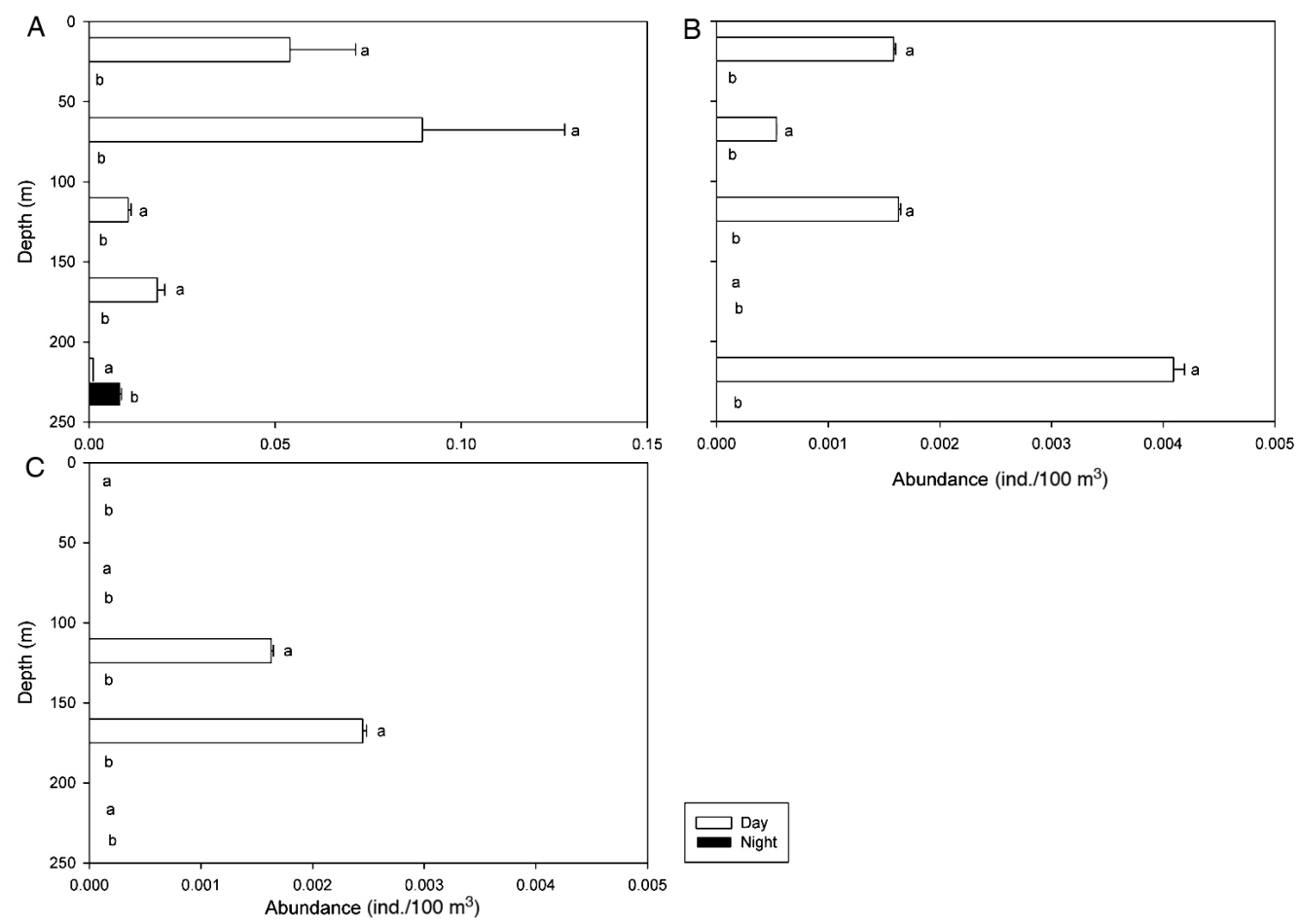

Fig. 4. - Monodaeus couchii. Abundance of larvae (ind./100 $\mathrm{m}^{3} \pm \mathrm{SE}$ ) with respect to depth for zoea I (A), zoea II (B), and zoea III (C) as a function of the phase of the day for the 2007 cruise. White and black bars represent day and night samples, respectively. At each depth, sample size was $n=4$ for the day, and $n=5$ for the night. Identical letters above bars represent statistically similar abundances acording to post-hoc tests. The scale of abundance is different between zoea I and zoea II, III and IV.
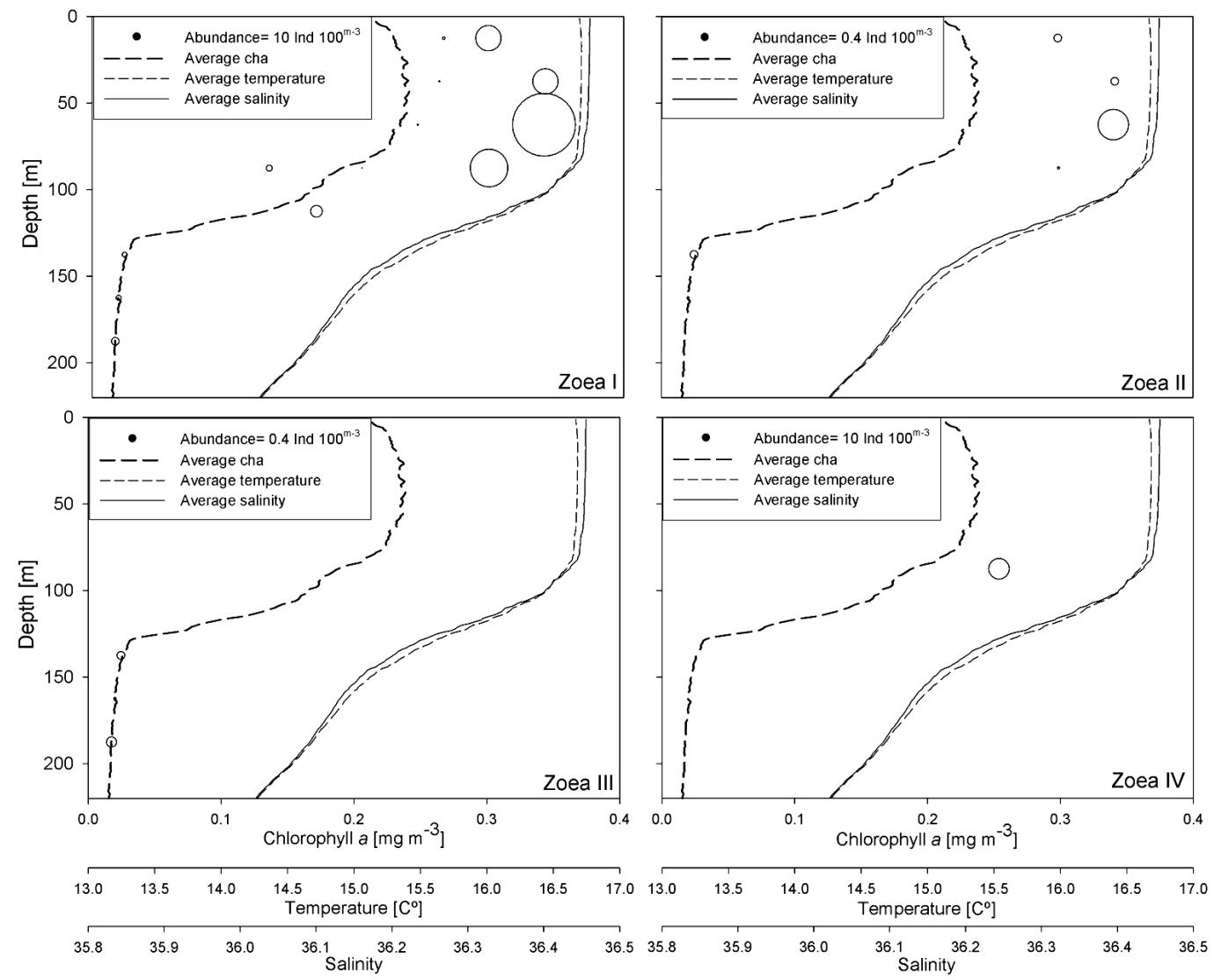

Fig. 5. - Monodaeus couchii. Standardized catch of zoea plotted as a function of depth ( $\mathrm{m}$ ) and chlorophyll $a$ concentration ( $\left.\mathrm{mg} \mathrm{m}^{-3}\right)$ during the 2007 cruise off the coast of Algarve. The size of the circle represents larval abundance. The lines represents the average profile of chlorophyll $a$, temperature $\left({ }^{\circ} \mathrm{C}\right)$ and salinity concentration calculated from measurements made at all the stations. 
between years might be explained by the scarcity of zoeae III and IV.

In 2007 chlorophyll $a$ levels had subsurface maxima between 30 and $70 \mathrm{~m}$, decreasing rapidly to about $180 \mathrm{~m}$ to become constant below that depth (Fig. 5). Temperature also decreased with depth and there was a sharp drop in temperature between 120 and $130 \mathrm{~m}$ indicative of a thermocline. The same pattern was observed for salinity, with a decrease in salinity located at the same depth range. Spearman correlations between environmental factors and the concentrations of larvae indicated that zoeae I concentrations were positively correlated with chlorophyll $a\left(\mathrm{r}_{\mathrm{s}}=0.27 ; \mathrm{p}=0.01\right)$, salinity $\left(r_{s}=0.23 ; \mathrm{P}=0.04\right)$ and temperature $\left(\mathrm{r}_{\mathrm{s}}=0.24 ; \mathrm{p}=0.03\right.$; all values significant at $\alpha=0.05$ probability level after Bonferroni correction). In contrast, concentrations of zoeae II were only positively correlated with levels of chlorophyll $a\left(\mathrm{r}_{\mathrm{s}}=0.24 ; \mathrm{p}=0.03\right)$. Zoeae III and IV were not correlated with any measured parameter. Catches of zoeae I and II were highest when chlorophyll $a$ was highest (Fig. 5).

\section{DISCUSSION}

Overall, larval abundance of Monodaeus couchii in 2006 was higher than in 2007. All larval stages were found at depths above $300 \mathrm{~m}$, with the early stages (I and II) concentrated in chlorophyll-rich layers (from surface to $100 \mathrm{~m}$ ), and the differences in abundance according to phase of day and depth indicate the occurrence of reverse diel vertical migration.

The occurrence of Monodaeus couchii larvae in the surface layer indicates that larvae hatching from benthic females on the slope and near mud volcanoes are able to ascend rapidly to the surface, crossing the thermocline around $120 \mathrm{~m}$, to feed in surface waters, as shown by the positive correlation between first stages and chlorophyll $a$. This migration to the surface is widespread among first stage crab zoeae and results from negative geotaxis and positive phototaxis barokinesis (Sulkin 1973, Ott and Forward 1976, Schembri 1982). Crab larvae are able to cross sharp pycnoclines during migration towards surface waters, and this has also been demonstrated in early zoeal stages of Geryon quinquedens (Kelly et al. 1982), another deep-water brachyuran. Average larval depth increased with larval stage, also in line with numerous reports showing a preponderance of positive geotaxis in older larvae (Sulkin 1973), taking larvae of later stages to deeper depth, especially at the transition to the megalopa stage that must settle to appropriate benthic habitats. In the case of M. couchii, megalopae will have to settle several hundred metres deeper on the seabed, which, together with the decrease in densities with age, would explain the absence of megalopae in our samples.

In zooplankton, diel vertical migration (DVM) behaviours vary inter-specifically (Han and Straskraba 2001). Species can undergo no migration or any of the three following types of migration (Forward 1988): 1) nocturnal DVM, the most common form in which larvae rise to surface water during the night to feed and sink below the photic zone during the day, 2) reverse DVM in which larvae rise to the surface during the day and sink to deeper water at night; and 3) twilight migration in which larvae undergo two upward migrations near sunset and sunrise. Even intraspecifically, DVM behaviour might vary with time, location (e.g. distance from coast) or environmental conditions such as fluctuations in predator or prey abundances or vertical stratification (Irigoien et al. 2004, Osgood and Frost 2004). In the present study, Monodaeus couchii was most abundant during the day in the top hundred metres of the water column, while at night abundance increased with depth. In the Algarve area, the data suggest that $M$. couchii underwent reverse DVM, which was most defined in the 2006 sampling period, probably due to the overall higher larval abundances observed.

Reverse DVM has been suggested as a defence against predators that also migrate vertically. As observed in various copepod species, when predators exhibit nocturnal DVM, their prey may undergo reverse DVM (Irigoien et al. 2004, Osgood and Frost 2004). This behaviour has been associated with areas where the predators rely more on tactile stimuli than sight to capture prey, as is the case for many invertebrate predators (e.g. chaetognaths and gelatinous zooplankton) which themselves are undergoing regular DVM as a way to escape fish predators (Tester et al. 2004). Reverse DVM has also been observed in areas with lower abundances of predatory fish (Lagergren et al. 2008). Since shifts in composition and abundance of predator populations occur, the prey must be able to adjust their behaviour accordingly, so temporal and geographical plasticity in DVM behaviour of Monodaeus couchii larvae could exist in response to changing environmental conditions.

The abundance of zoeae I and II was found to be positively correlated with chlorophyll $a$ levels. Two mechanisms might explain the correlation between the two factors. First, M. couchii larvae, their zooplanktonic prey and phytoplankton might be passively aggregated together due to hydrodynamic processes. Second, larvae responding to physical or biological factors might actively swim to avoid unsuitable environments (Folt and Burns 1999). In contrast, zoeae III and IV abundances were not correlated with chlorophyll $a$, which is explained by the highly variable depth distribution and very low abundances of these stages. Larger larvae might shift their diet to different, larger prey items that might be distributed more evenly in the water column, resulting in the observed pattern.

Our results indicate that newly hatched larvae of Monodaeus couchii, and probably of other open ocean benthic decapods, can migrate hundreds, if not thousands, of metres to the photic layers of the water column where food is more abundant. Late-stage larvae were encountered deeper, initiating the return migration to the sea bed. Following the first ontogenetic migration to surface layers, DVM behaviour of such species is relatively unknown. $M$. couchii appear to perform a reverse migration within the top $300 \mathrm{~m}$ of the ocean, but variability might exist in DVM behaviour depending on the species, location and environmental conditions. 


\section{ACKNOWLEDGEMENTS}

The authors thank Dr. Dave Conway and the crew of the RV Noruega for their indispensable support during the survey, Fátima Quintela for her help during sampling processing, Dr. Craig Young for his useful review of the manuscript, and Laura Garcia Peteiro and Laurence Zulianello for their help with the Spanish version of the abstract and the figure design, respectively. This work was supported by the Portuguese Science Foundation (Fundação para a Ciência e a Tecnologia-FCT) as a PhD scholarship to PNP [SFRH/BD/27615/2006] and the research grant LobAssess-Norway lobster stocks in Portugal: Basis for assessment using information on larval production and ecology [POCI/BIA-BDE/59426/2004, PPCDT/ BIA-BDE/59426/2004].

\section{REFERENCES}

Anger K. 2001. The biology of decapod crustacean larvae, Vol. Swets and Zeitlinger, Lisse.

Chia F.-S., Buckland-Nicks J., Young C.M. 1984. Locomotion of marine invertebrate larvae: A review. Can. J. Zool. 62: 1205-1222. http://dx.doi.org/10.1139/z84-176

DeVries M.C., Tankersley R.A., Forward Jr. R.B., et al. 1994 Abundance of estuarine crab larvae is associated with tidal hydrologic variables. Mar. Biol. 118: 403-413. http://dx.doi.org/10.1007/BF00350297

DiBacco C., Sutton D., McConnico L. 2001. Vertical migration behavior and horizontal distribution of brachyuran larvae in a low-inflow estuary: Implications for bay-ocean exchange. Mar. Ecol. Prog. Ser. 217: 191-206. http://dx.doi.org/10.3354/meps217191

dos Santos A., Peliz A. 2005. The occurrence of norway lobster (Nephrops norvegicus) larvae off the portuguese coast. J. Mar. Biol. Assoc. U.K. 85: 937-941. http://dx.doi.org/10.1017/S0025315405011914

dos Santos A., Santos A.M.P., Conway D.V.P., et al. 2008. Diel vertical migration of decapod larvae in the Portuguese coastal upwelling ecosystem: implications for offshore transport. Mar. Ecol. Prog. Ser. 359: 171-183. http://dx.doi.org/10.3354/meps07341

Eckelbarger K., Watling L. 1995. Role of phylogenetic constraints in determining reproductive patterns in deep-sea invertebrates. Invertebr. Biol. 114: 256-269. http://dx.doi.org/10.2307/3226880

Epifanio C.E., Garvine R.W. 2001. Larval transport on the atlantic continental shelf of north america: A review. Estuar. Coast. Shelf Sci. 52: 51-77. http://dx.doi.org/10.1006/ecss.2000.0727

Folt C.L., Burns C.W. 1999. Biological drivers of zooplankton patchiness. Trends Ecol. Evol. 14: 300-305. http://dx.doi.org/10.1016/S0169-5347(99)01616-X

Forward Jr. R.B. 1988. Diel vertical migration: Zooplankton photobiology and behaviour. Oceanogr. Mar. Biol. 26: 361-393.

Gonzalez-Gurriarán E., Méndez G.M. (eds). 1985. Crustáceos decápodos das costas de Galicia. I. Brachyura, Vol 2. Cuadernos da Área de Ciencias Biolóxicas, Seminario de Estudos Galegos, Ed. do Castro, 242 pp.

Han B., Straskraba M. 2001. Control mechanisms of diel vertical migration: Theoretical assumptions. J. Theor. Biol. 210: 305-318. http://dx.doi.org/10.1006/jtbi.2001.2307

Ingle R.W. 1983a. A comparative study of the larval development of Monodaeus couchii (couch), xantho incisus leach and Pilumunus hirtellus (Linnaeus) (Crustacea: Brchyura: Xanthidae). J. Nat. Hist. 17: 951-978. http://dx.doi.org/10.1080/00222938300770741

Ingle R.W. ed. 1983b. Shallow-water crabs. Keys and notes for the identification of the species, Vol 25. Cambridge University Press, London, $206 \mathrm{pp}$.

Irigoien X., Conway D.V.P, Harris R.P. 2004. Flexible diel vertical migration behaviour of zooplankton in the Irish Sea. Mar. Ecol Prog. Ser. 267: 85-97. http://dx.doi.org/10.3354/meps267085

Kelly P. Sulkin S.D., Heukelem W.F. 1982. A dispersal model for larvae of the deep sea red crab Geryon quinquedens based upon behavioral regulation of vertical migration in the hatching stage. Mar. Biol. 72: 35-43.

http://dx.doi.org/10.1007/BF00393945

Lagergren R., Leberfinger K., Stenson J.A.E. 2008. Seasonal and ontogenetic variation in diel vertical migration of Chaoborus flavicans and its effect on depth-selection behavior of other zooplankton. Limnol. Oceanogr. 53: 1083-1092. http://dx.doi.org/10.4319/10.2008.53.3.1083

Lindley J.A. 1986. Vertical distributions of decapod crustacean larvae and pelagic post-larvae over Great Sole Bank (Celtic Sea) in June 1983. Mar. Biol. 90: 545-549. http://dx.doi.org/10.1007/BF00409275

Maynou F., Sardà F. 1997. Nephrops norvegicus population and morphometrical characteristics in relation to substrate heterogeneity. Fish. Res. 30: 139-149. http://dx.doi.org/10.1016/S0165-7836(96)00549-8

Mileikovsky S.A. 1973. Speed of active movement of pelagic larvae of marine bottom invertebrates and their ability to regulate their vertical position. Mar. Biol. 23: 11-17. http://dx.doi.org/10.1007/BF00394107

Mullineaux L.S., Wiebe P.H., Baker E.T. 1995. Larvae of benthic invertebrates in hydrothermal vent plumes over Juan de Fuca Ridge. Mar. Biol. 122: 585-596. http://dx.doi.org/10.1007/BF00350680

Navarro G., Ruiz J., Huertas I.E., et al. 2006. Basin-scale structures governing the position of the deep fluorescence maximum in the Gulf of Cadiz. Deep-Sea Res. II 53: 1261-1281. http://dx.doi.org/10.1016/j.dsr2.2006.04.013

Osgood K.E., Frost B.W. 2004. Ontogenetic diel vertical migration behaviors of the marine planktonic copepods Calanus pacificus and Metridia lucens. Mar. Ecol. Prog. Ser. 267: 85-97.

Ott F.S., Forward R.B., Jr. 1976. The effect of temperature on phototaxis and geotaxis by larvae of the crab Rhithropanopeus harrisii (Gould). J. Exp. Mar. Biol. Ecol. 23: 97-107. http://dx.doi.org/10.1016/0022-0981(76)90134-9

Pearre S. 1973. Vertical migration and feeding in Sagitta elegans Verrill. Ecology 54(2): 300-314 http://dx.doi.org/10.2307/1934338

Pearre S. 2003. Eat and run? The hunger/satiation hypothesis in vertical migration: history, evidence and consequences. Biol. Rev. 78: 1-79. http://dx.doi.org/10.1017/S146479310200595X

Queiroga H., Blanton J. 2005. Interactions between behaviour and physical forcing in the control of horizontal transport of decapod crustacean larvae. Adv. Mar. Biol. 47: 107-214. http://dx.doi.org/10.1016/S0065-2881(04)47002-3

Rothlisberg P.C., Church J.A., Fandry C.B. 1995. A mechanism for near-shore concentration and estuarine recruitment of postlarval Penaeus plebejus Hess (Decapoda, Penaeidae). Estuar. Coast. Shelf Sci. 40: 115-138. http://dx.doi.org/10.1016/S0272-7714(05)80001-0

Schembri P.J. 1982. Locomotion, feeding, grooming and the behavioural responses to gravity, light and hydrostatic pressure in the stage i zoea larvae of Ebalia tuberosa (Crustacea, Decapoda, Leucosiidae). Mar. Biol. 72: 125-134. http://dx.doi.org/10.1007/BF00396913

Sulkin S.D. 1973. Depth regulation of crab larvae in the absence of light. J. Exp. Mar. Biol. Ecol. 13: 73-82. http://dx.doi.org/10.1016/0022-0981(73)90048-8

Tester P.A., Cohen J.H., Cervetto G. 2004. Reverse vertical migration and hydrographic distribution of Anomalocera ornata (Copepoda: Pontellidae) in the us south atlantic bight. Mar. Ecol. Prog. Ser. 268: 195-203. http://dx. doi.org/10.3354/meps268195

Tyler P.A., Young C.M. 1999. Reproduction and dispersal at vents and cold seeps. J. Mar. Biol. Assoc. U.K. 79: 193-208. http://dx.doi.org/10.1017/S0025315499000235

Tyler P.A., Young C.M. 2003. Dispersal at hydrothermal vents: A summary of recent progress. Hydrobiologia 503: 9-19. http://dx.doi.org/10.1023/B:HYDR.0000008492.53394.6b

Verity P.G., Redalje D.G., Lohrenz S.R. et al. 2002. Coupling between primary production and pelagic consumption in temperate ocean margin pelagic ecosystems. Deep-Sea Res. II 49: 4553-4569. http://dx.doi.org/10.1016/S0967-0645(02)00164-9

Young C.M. 2003. Reproduction, development and life history traits. In: Tyle P.A. (ed.) Ecosystems of the world, Vol 28: Ecosystems of the Deep Oceans, pp. 381-426. 